PP 15-22

www.iosrjournals.org

\title{
Study and Analysis of Solid Waste Management Challenges and Options for Treatment (Indian Villages)
}

\author{
M. S. Kadam ${ }^{1}$, S. S. Sarawade ${ }^{2}$, \\ ${ }^{1}$ (Department of Mechanical Engineering.,BMIT, Solapur) \\ ${ }_{2}^{2}$ (Department of Mechanical Engineering, M.E.S. College of Engineering, S.P. Pune University, India)
}

\begin{abstract}
Solid waste management is become a critical issue in Indian metros as well as rural areas. A challenge for the authorities in developing countries as the rate of generation of waste is very high. The impact of urban area's culture on the rural areas (villages) and improvement in paying capacity ? of rural people causes more solid waste generation in the villages. .Any development and change of lifestyle of the urban people attract the rural people leading to generate village solid waste The high waste generation rate is due to rapid industrialization \& technical societal developments. Waste generated at rural places creates major problems to environment pollution i.e. air pollution, water pollution. Soil pollution. Now a day presently it is not only the urban problem but also the village problems too. Hence there is a urgent need of the efforts to overcome these problems.

This paper focuses on the problems associated with the management of solid waste and the options for treatment. ( and designing a system to treat solid waste in a environmental friendly approach effectively.)
\end{abstract}

Key words - Solid waste, Energy generation, Segregation. Recyclable, Disposal of waste.

\section{INTRODUCTION}

Solid waste is a material, that is not useful and does not represent any economic value to its owner. To improve the quality of life of rural population, the management of village solid waste need to be improved(3). Different activities like food habit, living standard and earning capacity of people create more solid waste in Indian villages. Now a day, transportation facility is easily available for rural people, so they are well connected with urban areas causes the impact of living standard of urban people on the rural people(2).

The rapid urbanization and change life style has increased the waste load and thereby pollution loads on the urban environment to unmanageable and alarming proportions. The existing waste dumping sites are full beyond capacity and under unsanitary conditions leading to pollution of water sources, proliferation of vectors of communicable diseases, foul smell and odors, release of toxic metabolites, unaesthetic ambiance and eye sore etc. It is difficult to get new dumping yards. Constraints of land availability, dense population, environmental fragility and expectation for management of solid wastes relies on an overly centralized approach.

In earlier days, municipal wastes, comprised mainly of biodegradable matter, did not creates much problem to the community as the quantity of wastes generated was either recycled/ reused directly as manure or was within the assimilative capacity of the local environment. The biodegradable waste of the urban centers was accepted by the suburban rural areas for composting in the agricultural field. With increasing content of plastics and non-biodegradable packaging materials, municipal wastes became increasingly unacceptable to cultivators. As a result, the excessive accumulation of solid wastes in the urban environment poses serious threat. Similar scenario is now emerging in rural areas as well due to the urban-rural continuum, Now, dealing with waste is a major challenge.

In village level the solid waste increases due to agricultural waste, Domestic waste, Animal waste. The objective of rural solid waste management is to collect waste at the source of generation, Recovery of the recyclable materials for recycling, conversion of organic waste to compost and secured disposal of remaining waste .Depending on the physical state of waste, it is categories in to municipal waste, hazardous waste , medical waste , and radioactive waste( 1 ). 


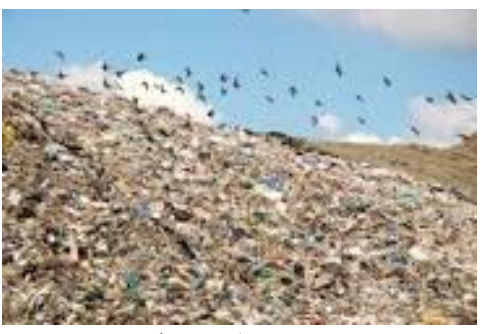

Photo-1

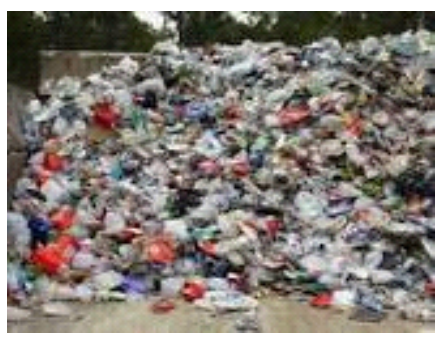

Photo-3

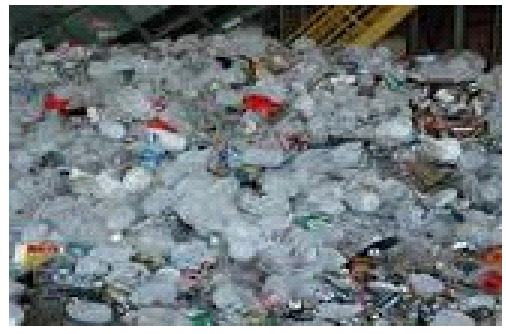

Photo-2

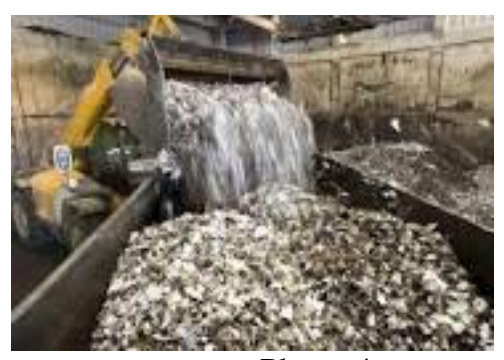

Photo-4

Fig. 1 Photographs of solid waste generation in metros, dumping sites, not proper disposal of solid waste and its effect on environment

\section{LITERATURE SURVEY}

The different aspects for literature survey are, generation of solid waste, Treatment of solid waste and management of solid waste.

\subsection{Generation of solid waste:}

Over last ten years, the handling of waste - Including reuse and recycling, collection, treatment, and disposal is improving in cities, but is limited in rural areas.

Table 1 gives the quantities of solid waste in Vietnam. (Ref.2)

\begin{tabular}{|l|l|}
\hline Municipal Solid waste generation ( tons/yr) & 12800.00 \\
2) National & 6400.00 \\
3) Ruran areas & 6400.00 \\
\hline Hazardous waste by Industries & 128,400 \\
\hline Non hazardous waste generation & 2510,00 \\
\hline Hazardous health care waste generation & 21000 \\
\hline Hazardous waste generation from agriculture & 8600 \\
\hline Amount of stockpiled agriculture chemicals & 37000 \\
\hline $\begin{array}{l}\text { Municipal Solid waste generation by each person } \\
\text { (kg/day) }\end{array}$ & 0.4 \\
1)National & 0.7 \\
2)Urban & 0.3 \\
3)Rural & \\
\hline $\begin{array}{l}\text { Collection of waste (\% of waste generated ) } \\
\text { 1) Urban areas }\end{array}$ & $71 \%$ \\
2) Rural areas & $<20 \%$ \\
3) Among Urban poor & $10-20 \%$ \\
\hline $\begin{array}{l}\text { No of solid waste disposal facilities } \\
\text { 1) Dumps and poorly operated landfills } \\
\text { 2) Sanitary landfills }\end{array}$ & 74 \\
\hline Capacity for hazardous waste treatment (\%) & 17 \\
\hline
\end{tabular}


The quantity of municipal solid waste generated depends on a number of factors such as food habits, standard of living, degree of commercial activities and seasons. Data on quantity variation and generation are useful in planning for collection and disposal systems. Indian cities now generate eight times more MSW than they did in 1947. Because of increasing urbanization and changing life styles [14]. The rate of increase of MSW generated per capita is estimated at 1 to $133 \%$ annually [15-16]. MSW generation rates in small towns are lower than those of metro cities, and the per capita generation rate of MSW in India ranges from 0.2 to $0.5 \mathrm{~kg} /$ days. It was also estimated that the total MSW generated by 217 million people living in urban areas was 23.86 million $\mathrm{t} / \mathrm{yr}$ in 1991, and more than 39 million ton in 2001 [18-22]. The Central Population Control Board (CPCB) has conducted a survey of solid waste management in 299 cities and has given the data (Table - 2) of waste generation for different cities. From above survey is clear that whatever are the issues discussed uptil are related to only urban areas and the metropolitan cities, i.e. MSW management, generation of solid waste, and treatment of solid waste. So it also important to concentrate on village level areas solid waste management.

2.2 Sources of VSW In Indian Villages - In village level major solid waste sources are the residential, Institutional, and agricultural activities.

Table No. 2 Sources of VSW In Indian Villages

\begin{tabular}{|l|l|l|}
\hline Sources & Typical Waste generators & Componenets \\
\hline Residential & $\begin{array}{l}\text { Single \& multi family } \\
\text { dwellings }\end{array}$ & $\begin{array}{l}\text { Food waste, garbage , paper ,cardboard, } \\
\text { plastics, Textiles, glass, metal, ashe, special } \\
\text { waste ( bulky items, consumer electronics, } \\
\text { batteries, Oil, Tires) Leather, rubber, Earth, } \\
\text { ceramics. }\end{array}$ \\
\hline Institutional & $\begin{array}{l}\text { School, small hotels, } \\
\text { markets, office buildings. } \\
\text { Small hospitas. }\end{array}$ & $\begin{array}{l}\text { Paper, cardboard, plastics, wood, food waste, } \\
\text { Glass, metals Thermocol. }\end{array}$ \\
\hline Aggriculture & Farmers, Animals, & $\begin{array}{l}\text { Wood, Earth,Cow dung,Animal waste, leaves, } \\
\text { tree strings, grass, cattle food waste. }\end{array}$ \\
\hline Drainage & Public, Natural & Mud, Silica, Earth \\
\hline
\end{tabular}

1. In VSW wih increasing content of plastics and non- bio degradable packaging materials, It becomes unacceptable to cultivators.

2. Basically VSW is divided into four types. Dry waste, Weight waste, Raw material, ( mud, drainage, waste, silica) and medical waste.

Dry waste are generated by the households, commercials and institutional establishments and Agri waste. Weight waste ( garbage, food waste) is generated due to household, small hotels, markets. Raw materials quantity in VSW is major, because in villages open drainage system is there, At the time of cleaning major raw material is collected which is consists of mud and silica. Medica waste is very small quinty because one or two dispensaries are there. Agri waste mainly consists of grass, remaining food of cattles, Cattles dung ( depen on the animals quinty). In this way VSW consists of Organic and Inorganic waste.

\subsection{Generation of VSW}

The generation of solid wste in villages is in between $50 \mathrm{gm} / \mathrm{cap} /$ day to $250 \mathrm{gm} / \mathrm{cap} /$ day.

Rural (Peri urban or urban outgrowth) - 150 to $250 \mathrm{gm} / \mathrm{cap} /$ day.

Rural (Remote/ Tribal ) - $\quad 50$ to $150 \mathrm{gm} / \mathrm{cap} /$ day. ( 3 )

\subsection{Treatment of solid waste:}

The technology options available for processing the Municipal Solid Waste (MSW) are based on either bio conversion or thermal conversion. The bio-conversion process is applicable to the organic fraction of wastes, to prepare compost or to generate biogas such as methane (waste to energy) and residual sludge (manure). Various technologies are available for composting such as aerobic, anaerobic and vermin-composting. The thermal conversion technologies are incineration with or without heat recovery, pyrolysis and gasification, plasma pyrolysis and pelletization or production of Refuse Derived Fuel (RDF). A brief account of these technologies is essential for evaluating their efficiency, applicability and impacts. He also suggested diff. 

processes for MSW. i.e .composting, Bio-waste period fuel, vermi composing, Incineration plasma pyrolysis.(Ref.1)

India is facing the problems related to resources required for disposal of MSW. i.e. Land, segregation machinery. and the technical expertise necessary to deal with the disposal of MSW. Waste dumps or open burning continue to be the principal method of waste disposal in India. These methods causes several accidents are continuous source of emission of harmful gases and highly toxic liquid leachate..He discussed some other methods are composting, Incineration, gasification technology ,RDF plants, Land filling,(Ref.3)

Thermo chemical treatment process are an essential component of a sustainable integrated MSW management system. Thermal process made the energy value of solid waste into different types such as electricity and heat processes. The main thermo chemical process are combustion, pyrolysis and gasification.(Ref.10).

\subsection{Management of municipal solid waste}

Sustainable waste management systems through the adoption of Integrated Solid Waste Management (ISWM) are analyzed as a probable solution towards solving the hazards and complexities posed by current waste management problems. Existing literature inclusive of all available sources of information used to analyses current waste management systems in the country, (Ref.7).

The need to form regulatory institutions for inspection of solid waste management practices. To create the incentives for minimization of solid waste. To establish hazardous waste management system for each economic zone. In line with a growing concern about sanitation issues, embracing both solid and liquid waste management system in urban and rural areas. It is a need to promote sanitation strategy and action plan for country, which will provide a clear basis for planning, funding, and implementing projects and activities in a more integrated way. (Ref.2)

In India there is no any scientifically planned source for segregation except for industrial waste where due to organized nature of sector. Those materials are only segregated

Which have relatively higher economic return in the recycling market. The unsafe and hazardous conditions under which the segregation and sorting takes places are well known. The waste collection efficiency is very low in high economic cities. some amount of solid waste is left on the street and is dumped in low lying areas, canals, rivers.(Ref.3).

2.5. Hierarchy of sustainable waste management- In villages every family collects the solid waste and dump openly near the house called it as ( ukirda) which is generated in house and by the animals and Agri activity. There is no any well established system for collection and treatment of solid waste which has become a serious problem for rural environment and effects on the rural life style. Following figure shows different options hierarchy of Solid waste management at village level.

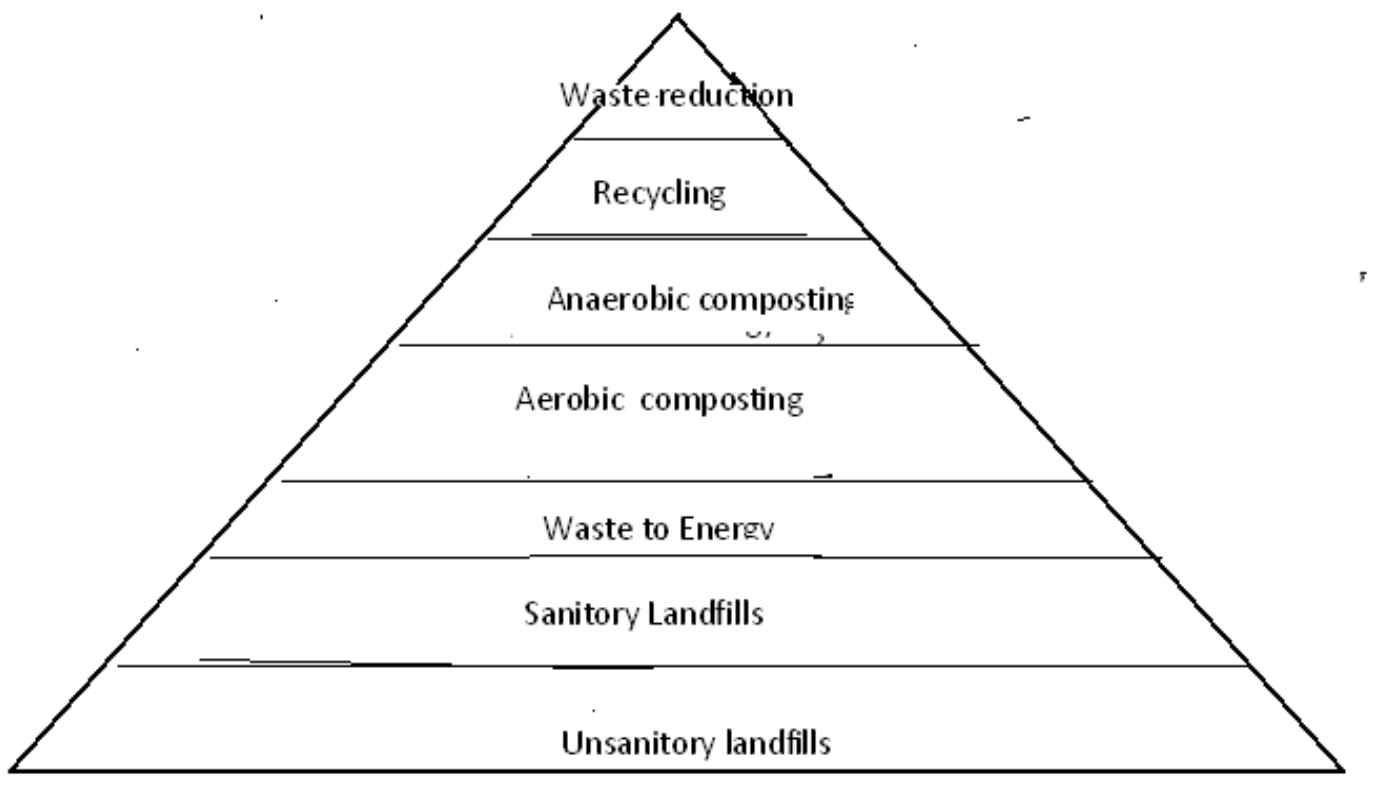

Fig.1 Hierarchy of sustainable waste management 
The hierarchy shows (Fig.1) that the waste reduction and reuse of the waste materials are the better options for minimizing the generation of waste, But it is not possible upto zero level. Once the waste is generated it need to be collected, recycling, composting and remaining for waste to energy for effective waste handling. The last option is open burning and unsanitary landfills (1).

\section{PROBLEMS ASSOCIATED WITH SOLID WASTE MANAGEMENT AT VILLAGE LEVEL}

3.1 Collection and storage of solid waste : Most of villages solid waste is collected traditionally. In this method every family collect the solid waste separately near the house. There is no any segregation of solid waste. Total land engaged for this purpose is more and it became a non -productive. Solid waste dumped openly in this method on the common areas, so animals scattered anywhere. Local authority has no sufficient source for purchasing the vehicles. As well as high maintenance cost of vehicles. so collection of solid waste becomes a crucial step in management of solid waste at village .

3.2 Segregation of solid waste : The general characteristics of solid waste at village level are cow dung, garbage, ash, earth, paper. i.e organic and inorganic materials. The inorganic materials onsists of recyclable and non recyclables. For the composting purpose only cow dung is separated but other solid waste is mixed and openly dumped in living area, canals, rivers etc. For segregation purpose required machinery is available in metro city because there collection of solid waste. quantity of is more and earning of local authority is also high, but at village level quantity of solid waste. and earning of the local authority are the constraints in this process.

3.3 Treatment and Disposal of S.W. -At metros the treatment and disposal of S.W. plants are well established. At village level that much awareness is not in people and Government is also not serious about village level problem, so government not giving the funds.

3.4 Lack of Awareness of people- In India literacy is near about 50\% to $60 \%$ that is the major obstacle for solid waste management. People generates solid waste and throw it in living areas openly, on the roads, near the water sources. So it becomes very difficult to collect and process it. There is lack of awareness in people about the effect of solid waste on environment and health.

\section{SOLUTION FOR SOLID WASTE MANAGEMENT AT VILLAGE LEVEL.}

\subsection{Collection and storage of solid waste}

In urban areas collection of solid waste by the vehicles because the quantity is more, But in rural areas that much quantity is not generated, so use the small vehicles having load carrying capacity is upto 4 to 5 tons.

- Use the manual system for solid waste. collection by using small trolleys, bullock cart.

- To provide separate low yield land for 50 to 100 families for storage of Solid waste.

- It is necessary to collect the solid waste from door to door.

\subsection{Segregation of solid waste}

For metropolitan cities automated big capacity units are used for segregation purpose. But at villages less generation of solid waste scale down that units up to capacity 100 to 200 tons/day.

- House segregation (organic\& inorganic/recyclable/non recyclable)

- House storage( separate bins)

- To motivate the people, give the financial support for segregation of recyclable items.

4.3 Treatment and Disposal of S.W.

In urban areas treatment is done on the solid waste and generate the electricity, production of ice, and for cold storage purpose. Above all units are very high capacity. We can design the small units for village level for generation of electricity having capacity 1 to 2 mega watts, due to this every village become independent for electricity

- Recycling of waste ( inorganic material)-Major recycling S.W.at village level is papers, polythene bags, plastic, and few metal parts ( Agri related parts).

$5^{\text {th }}$ National Conference RDME 2016, 10-11 $1^{\text {th }}$ March 2016. 
- Non recyclable waste- This waste could be disposed by secured land filling operation.

1) Filling of low yield land

2) No risk of ground water and surface water pollution.

3) Compaction of fill

4) Earth cover after filling.

5) Land reclamation

6) Landscape development

7) Use of land for horticulture, playground, recreation park. assimilative

- Conversion of organic waste to compost

- Household level composting by organic waste converter

- Vermi composting

- Energy generation from S.W. \& production of ice, cold storage

\subsection{To create the awareness}

- To start from education field, Include in the syllabus at high school level about Importance of solid waste and its effect on environment. and remedies.

- Appoint 'NGO' for awareness of people and organize various camps, poster exhibition ,documentary films and the campaigning at weekly markets.

- Expecting the cooperation from local authorities i.e. Grampanchayat and other social workers to establish a proper system to collect the solid waste every day.

- Compulsion for every family to provide a separate space for storage of solid waste.

- To make it mandatory for every government servant to take active participation in all the activities related to solid waste management.

- Take disciplinary action against these people, who are not following the rules and regulations.

\section{PROPOSED OPTIONS FOR TREATMENT OF VILLAGE SOLID WASTE (VSW)-}

4.1 Recycling: It is plays an important role in reducing the impact of VSW on environment and public health. It is knows $\mathrm{n}$ that $95 \%$ elements of the solid waste impacts on the environment and human life before it discarded. In villages there is a traditional method for collection of recycling material from door to door by a informal traders called as ( kabadiwala) and then thy are separated that material like metal, plastics, rubber, leather, papers etc. But $100 \%$ separation of this material is very tedious and time consuming job. So, remaining residues can be used for RDF and WTE plants to avoiding landfilling.

\subsection{Aerobic Compositing :}

Sources of village organic waste are household waste food waste from a small restaurant, vegetable markets, animal, waste these water are used for compost and it is used for agricultural fields .Organic composts consist of rich nutrients like nitrogen, phosphorus \&potassium \& Other micronutrients. But the quality of compost product depends upon the quality of the organic waste. In this waste there is mixed waste so compost quality becomes low \& less useful. And has the potential to introduce to heavy metal into the human food chain so this contaminated compost is not for agriculture use therefore it is not an option for sustainable management (1) .

4.3 Anaerobic composting : In this process microorganism break down organic materials such as cattle's waste,(cow dung) manure \& sewage sludge in the absence of the oxygen. It is also called as biomethaniation. The energy which created in this method in the form of biogas and compost as liquid residual. Biogas consists of methane (ch4) \& carbon dioxide (co2) can be used for fuel and the liquid slurry is used for organic fertilizer .Again contamination of the feed disturbs the process for village level.Small type of biogas plant are possible and best option for sustainable solid waste management, but it is depends upon the solid waste generated by family and animal waste.

4.4 Waste to energy combustion (WTE) : In this prossess village solid waste is used for creating a energy like electricity, steam. The VSW in enclosed in device for combustion and the residue will be an ash.It is the best option for the handling of the mixed village solid waste because the residue of this process (bottom ash) contains inert inorganic materials and minerals, which could be used for construction material. This process decreases the volume of wastes, which is useful to prolong the life of landfill for many years. The VSW should 

be composted after all, possible recycling and composting has been done. The input of this process should be the rejects from material recovery. So it is best option for sustainable VSW.

4.5 Sanitary Landfilling-The remaining waste is sanitary landfill. It is the last option for VSW. Following three conditions are necessary to fulfil it.

a) Compaction of waste b) Daily covering of waste (with soil or other material) c) Control and prevention of negative impacts on public health and the environment.

4.5. Comparision- Anaerobic composting is better option as compared to aerobic composting, because the residue of the Anaerobic composting is again used for the agricultural use. i.e. compost. If we compare above both option with the waste to energy.WTE is the best option for village solid waste treatment because the mixed solid waste can be used as input for the energy generation. So major volume of VSW is consume in this process.

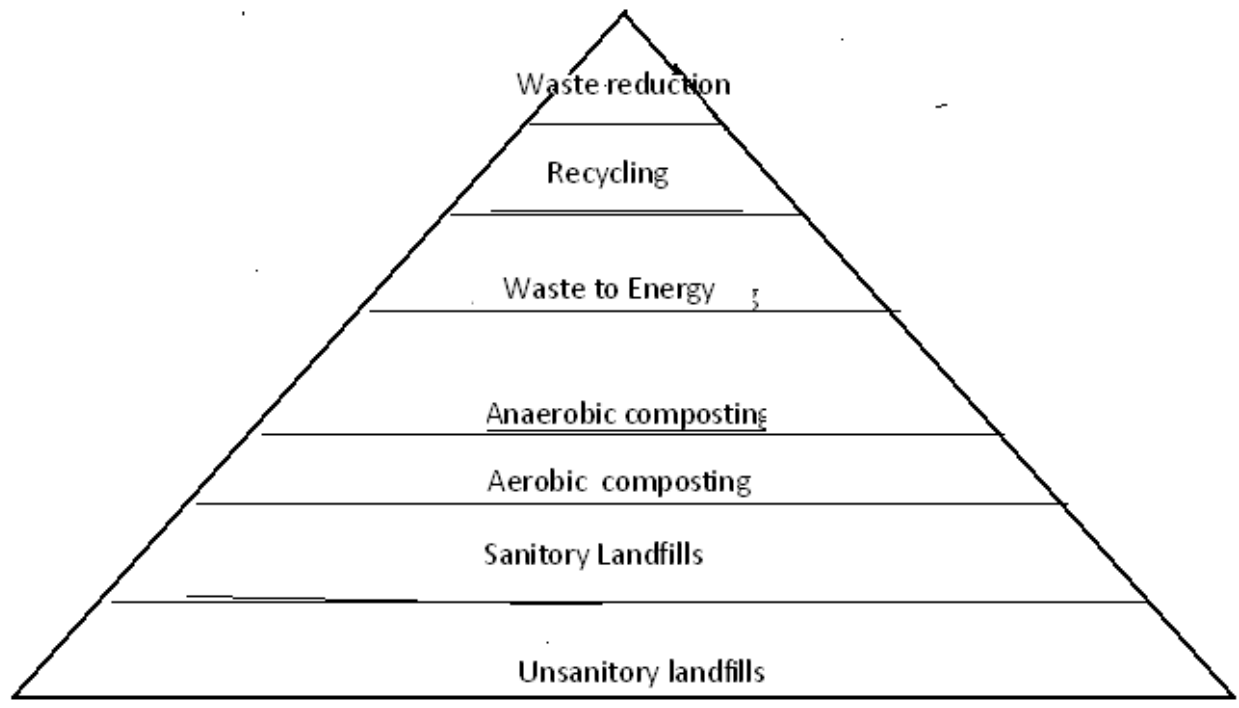

Fig. 2 Best options hierarchy of Solid waste management at village level

\section{CONCLUSION}

Probable solutions for solid waste management at village level :

1) Collection and storage of solid waste 2) Segregation of solid waste 3) Treatment and Disposal of S.W.

4) To create the awareness

So after above study following options are very beneficial for the VSW treatment. Aerobic composting is the traditional method, Anerobic composting is not well in practice due to initial cost. WTE is the better option in this energy crises, WTE fulfills the need of electricity of village and steam generation for the other use.So first manufacture the proto type model for treatment of VSW is necessity to face this problem.

1. Waste to energy is the better option in this energy crises because $80 \%$ of village solid waste is used as fuel for Energy generation.

2. Waste to energy fulfills the need of electricity of village and steam generation for the other use.

3. Development of proto type model for treatment of VSW is necessary.

\section{REFERENCES}

[1] R Ajay Kumar Varma, "Technology options for treatment for municipal solid waste with special www.sanitation .Kerala .gov.in /pdf workshop/technoz.pdf

[2] P. syliem, "Handling of solid waste in Vietnam" http//www.vncold.vn.

R. K. Kausal, G. K..Varghese," Municipal solid waste management in India current state and future challenges.” International Journal of Engg. Science \& Technology, .4 (4), 2012. 
Study \& Analysis of Solid Waste Management Challenges \& Options For Treatment (Indian Villages)

[3] S. Rathi," Optimization model for integrated municipal solid waste management in Mumbai, India." Environment and development Economics, 12 -2007.55

[4] O. Schwarz-Herion, A. Omran, H. Rapp, "A case study on successful municipal solid waste management in Industrialized countries by the examples of Karesrule city.”Journal of Engg annals of Faculty of Engg. Hunedoara-2008 Fascicule 3 ,(ISSN-1584-2873.

[5] K. Hadjibiros, D Dermatas, "Municipal Solid waste mgmt. \& landfill site selection in Greece; $\quad$ Irrationality $\quad$ Versus efficiency" Globel Nest Journal 13(2),150-161, 2011.

[6] M. Saleh A. Ansari, “ Municipal Solid waste mgmt system in the Kingdam of Bahrain; Resurces and Environmental Engg. 4(5),150-161,2012.

[7] A. Babalola, I. Basu, "Selection of Landfill sites for solid waste Treatments in Damaturu Town using GIS Techniques ." Journal of Environmental Protection, 2011,2,1-10.

[8] L. A. Guerrero, Germass,"Solid waste management challenges for cities in developing rediff.com/bn/downloadajax.cgi.

countries"http//f4check

[9] U. Arena, "Process \&technological aspect of municipal solid waste gasification- A 32,- 2012, pp-625-639.

review."Journal of waste management, 